ROCZNIKI TEOLOGICZNE

Tom LXVIII, zeszyt $4-202$

DOI: https://doi.org/10.18290/rt21684-3

\title{
ECHA REPRESJI WOBEC KLASZTORÓW W KRÓLESTWIE POLSKIM NA ŁAMACH KRAKOWSKIEGO CZASU PO UPADKU POWSTANIA STYCZNIOWEGO
}

\author{
ECHOES OF REPRESSION AGAINST MONASTERIES \\ IN THE KINGDOM OF POLAND IN KRAKOW'S DAILY CZAS \\ AFTER THE COLLAPSE OF THE JANUARY UPRISING
}

\begin{abstract}
The journal Czas (Time), a newspaper of Galician conservatives published in Krakow beginning in 1948, covered events in the Kingdom of Poland related to the January Uprising and repressions of the tsarist government against Poles after its collapse. One of the journal's main themes was repression of the Catholic Church, especially male and female religious orders. It described all forms of harassment of monastic peoples by the Russians: petty mailce, issuance of regulations impeding the normal functions of monasteries, moral torment, torture, execution, exile to Siberia, confiscation of monastic property, and finally, liquidation of most male and female monasteries. When reporting cases of repression, the journal also presented the reactions of Western powers and the papacy to the anti-Polish and anti-church policy of the tsarist regime, as well as ineffective diplomatic attempts to counter such repressions. For a long time, readers were deluded by the hope of intervention from the Western powers on behalf of the oppressed Polish nation in defense of both national ideas and the Catholic religion. Unfortunately, this hope, which was bitterly reported by Czas, turned out to be in vain.
\end{abstract}

Keywords: Kingdom of Poland; January Uprising; Krakow's Daily Czas; repression; male and female monasteries.

Wydarzenia lat 1861-1864 w Królestwie Polskim i represje władz carskich po upadku powstania styczniowego wobec jego uczestników, ludności cywilnej i Kościoła były na bieżąco relacjonowane i komentowane w prasie

Dr PATRYCJA GĄSIOROWSKA - doktor nauk humanistycznych, Instytut Historii PAN Zakład Polskiego Słownika Biograficznego; adres do korespondencji: ul. Sławkowska 17, 31-016 Kraków; e-mail: gasiorowska@ih.pan.krakow.pl; ORCID: https://orcid.org/0000-0001-8616-1945. 
zagranicznej i krajowej, ukazującej się w trzech zaborach. Z szeregu tytułów prasowych wychodzących $\mathrm{w}$ tym okresie $\mathrm{w}_{\text {Galicji }}{ }^{1}$, jednym $\mathrm{z}$ najbardziej poczytnych dzienników był krakowski Czas, ceniony ze względu na rzetelność przekazywanych informacji o bieżących wydarzeniach politycznych, gospodarczych, społecznych i kulturalnych z kraju oraz ze świata ${ }^{2}$. Wśród badaczy kultury i historyków istnieje zgodny pogląd, że gazeta reprezentowała najwyższy poziom merytoryczny i dziennikarski oraz wysoką kulturę polityczną, dzięki wyważonym opiniom i stonowanym komentarzom aktualnych wydarzeń, chociaż równocześnie nie stroniła od czasem dość ostrych polemik i replik ${ }^{3}$. Te niewątpliwe atuty Czasu w krótkim okresie pozwoliły mu stać się gazetą nie tylko opiniotwórczą, ale wręcz autorytetem i wyrocznią, głównie w sprawach politycznych. Wpływ na to mieli zarówno wysoko wykwalifikowani, ze sporym doświadczeniem dziennikarskim, redaktorzy gazety i felietoniści, jak i również korespondenci krajowi i zagraniczni, wśród których byli czołowi politycy galicyjscy, profesorowie wyższych uczelni, ludzie kultury, sztuki, pisarze i literaci ${ }^{4}$. Czas był ponadto dobrze zorganizowanym i sprawnie działającym przedsiębiorstwem prasowym, ze stałym i regularnie opłacanym personelem redakcyjnym, administracyjnym i drukarskim ${ }^{5}$. Od roku 1861 siedzibą redakcji i drukarni był nieistniejący obecnie dwór Kirchmajerów, zwany też Pałacem Steinkellera, usytuowany u wylotu ulicy św. Tomasza na Planty od strony obecnej ulicy Westerplatte ${ }^{6}$.

Dziennik ukazywał się zazwyczaj sześć razy w tygodniu (za wyjątkiem niedziel i świąt) z licznymi dodatkami, np. literackim, kulturalnym, prawniczym, rolniczym itd. Przeważnie składał się z czterech, czasami sześciu stron ze stałym układem rubryk. Kolportowano go do wszystkich zaborów, a także wielu krajów europejskich, miał też 6 zagranicznych agencji sprzedaży ${ }^{7}$.

\footnotetext{
${ }^{1}$ Jerzy Łojek, Jerzy Myśliński, Wiesław Władyka, Dzieje prasy polskiej (Warszawa: Interpress, 1988), 58.

2 Jerzy Drobiszewski, „Serwis informacyjny dziennika 'Czas' w latach 1848-1865”, Zeszyty Prasoznawcze (1968), 9, 1: 74-86. Zdarzało się także, że informacje były bałamutne, a przekazywane telegraficznie niejednokrotnie przekręcone. Często docierały również z dużym opóźnieniem. Były to jednak w owych latach mankamenty trapiące wszystkie gazety krajowe i zagraniczne.

${ }^{3}$ Adam Bańdo, „Krakowski 'Czas' (1848-1939) na tle dotychczasowych badań krakowskiej prasy”, Rocznik Historii Prasy Polskiej (2010), 13, 1-2: 92.

${ }^{4}$ Mariusz Jakubek, „Krakowski 'Czas' - środowisko dziennikarskie w latach 1848-1918”, Zeszyty Naukowe Uniwersytetu Jagiellońskiego (2005), 1279 (Prace Historyczne, 132), 165.

${ }^{5}$ Bańdo, „Krakowski ‘Czas' (1848-1939)”, 93.

${ }^{6}$ Adam Bańdo, „W 'rezydencji’ krakowskiego 'Czasu' (1848-1934)”, Rocznik Historii Prasy Polskiej (2014), 17, 2: 90-91.

${ }^{7}$ Jerzy Drobiszewski, „Kręgi czytelnicze 'Czasu' w latach 1848-1865, Studia Historyczne (1969), 12, 3: 386.
} 
W latach 1863-1864 Czas posiadał największą ze wszystkich gazet liczbę prenumeratorów, ok. 2460 osób, przyjmując zaś, że każdy egzemplarz czytały co najmniej 3-4 osoby, liczbę czytelników dziennika w tym okresie należy szacować na 3-7 tysięcy ${ }^{8}$.

W latach 1863-1864 z wiadomości o wydarzeniach na ziemiach polskich w krakowskim dzienniku dominowały szczegółowe doniesienia o powstaniu w Królestwie Polskim i na Litwie, relacje z procesu Polaków w Berlinie oraz przegląd bieżących wydarzeń w Krakowie i w Galicji. W miarę możliwości dość szeroko opisywano wszelkie przejawy represji wobec Polaków ze strony władz zaborczych, ze zrozumiałych względów najwięcej z terenów zaborów rosyjskiego i pruskiego. Wiadomości zagraniczne, zawarte w dzienniku, dotyczyły głównie polityki europejskiej, relacji z wojny w Stanach Zjednoczonych, również wydarzeń z innych krajów, np. z Chin czy Meksyku oraz opisy życia wyższych sfer, dworów i rodzin panujących monarchów. Dużo miejsca poświęcano $\mathrm{w}$ gazecie sprawom Kościoła i papiestwa oraz samej osobie papieża Piusa IX, a także zamieszczano przedruki encyklik i innych dokumentów kościelnych. Przeważnie informacje były komentowane, czasami jednym zdaniem, a czasami dłuższymi felietonami, przy czym daje się zauważyć, że artykuły odredakcyjne były bardziej umiarkowane, podczas gdy korespondenci zagraniczni lub też felietoniści zewnętrzni pozwalali sobie często na dość stanowcze reakcje wobec bieżących wydarzeń, nierzadko pełne patetycznych sformułowań ${ }^{9}$. Artykuły i informacje, zawarte w Czasie, cytowano i komentowano w prasie zagranicznej, a dziennik zawierał również najświeższy przegląd prasy zagranicznej, chociaż w przeważającej mierze tych doniesień i komentarzy, które dotyczyły spraw polskich ${ }^{10}$.

Czas był organem prasowym konserwatystów galicyjskich. W sferze ideologicznej propagował ściśle określony system wartości, zgodny z nauką i poglądami Kościoła katolickiego, w sferze socjalnej nienaruszalność istniejącego porządku społecznego, w sferze politycznej zaś lojalność wobec monarchii austro-węgierskiej oraz nieprzejednane, wręcz wrogie stanowisko wobec wszelkich ruchów rewolucyjnych ${ }^{11}$. Dzięki propagowaniu zachowawczej ideologii, broniącej podstaw wszelkich społeczeństw, takich jak: religia,

\footnotetext{
${ }^{8}$ Tamże, 383.

${ }^{9}$ Kazimierz Olszański, „Krakowski 'Czas' wobec powstania styczniowego”, w: Kraków w powstaniu styczniowym, red. Kazimierz Olszański (Biblioteka Krakowska, nr 113), (Kraków: Wydawnictwo Literackie, 1968), 226.

${ }^{10}$ Bańdo, „Krakowski ‘Czas’ (1848-1939)”, 92.

${ }^{11}$ Tamże, 87-88.
} 
własność, rodzina i poszanowanie władzy ${ }^{12}$, dziennik reprezentował głównie interesy ziemiaństwa i duchowieństwa ${ }^{13}$, ale również chętnie był czytany przez mieszczan, urzędników, inteligencję miejską, a także prenumerowany przez różne instytucje ${ }^{14}$. Pierwszy jego redaktor naczelny, Paweł Popiel (1807-1910), jeden z czołowych konserwatystów galicyjskich, pisał w swym pamiętniku, że był to dziennik katolicki, ale nie kościelny tylko polityczny ${ }^{15}$. Gazeta posiadała też licznych wrogów, a jednym z jej najbardziej zajadłych krytyków był działacz polityczny i niepodległościowy, generał Ludwik Mierosławski, który używał na określenie dziennika niewybrednych epitetów, nazywając ją „ewangelią lokajsko-klerykalną” czy „kałem lokajsko-jezuickim”16.

Od początku lat sześćdziesiątych XIX w., pod wpływem wydarzeń w zaborze rosyjskim, poglądy członków redakcji zaczęły ewoluować i stopniowo odchodzili oni od legitymistycznego nastawienia. Rzetelnie, na bieżąco opisywano i komentowano wszelkie przejawy bezwzględnej, wynaradawiającej polityki Rosjan wobec Polaków, co starano się udokumentować, przedrukowując urzędowe dokumenty, zarządzenia i ukazy władz carskich ${ }^{17}$. Mimo to w styczniu 1863 r. w artykułach zamieszczanych w gazecie ubolewano nad wybuchem powstania, uważając go za beznadziejny krok rozpaczy. Swoje stanowisko redakcja zmieniła, gdy Austria, Francja i Anglia stanęły po stronie narodu polskiego. Można powiedzieć, że gazeta została porwana przez rozwój wypadków, bowiem wkrótce przemieniła się w rzecznika i obrońcę powstania styczniowego, a pochwalając zarówno walkę orężną, jak i wszelkie inne możliwe formy oporu ${ }^{18}$, stała się wręcz gazetą rewolucyjną, organem opozycji narodowej i wyrazicielem patriotycznych uczuć społeczeństwa $^{19}$. Sporo miejsca na łamach $C z a s u$ zajmowały relacje z przebiegu walk zbrojnych na terenie Królestwa i opisy różnych przejawów obywatelskiego nieposłuszeństwa względem władz rosyjskich. Zespół dziennika zdawał sobie jednak sprawę $\mathrm{z}$ tego, że niektóre informacje, dochodzące do redakcji, są

\footnotetext{
${ }^{12}$ Kazimierz Adamek, „Geneza i wstępny program krakowskiego 'Czasu’”, Kwartalnik Historii Prasy Polskiej (1980), 19, 1: 29.

${ }^{13}$ Bańdo, „Krakowski 'Czas' (1848-1939)”, 88.

${ }^{14}$ Drobiszewski, „Kręgi czytelnicze 'Czasu'”, 383.

15 Adamek, „Geneza i wstępny program”, 33.

${ }^{16}$ Olszański, „Krakowski “Czas' wobec powstania”, 256.

${ }^{17}$ Krzysztof Figiela, „Echa powstania styczniowego na łamach 'Czasu' i 'Gazety Narodowej”, Zeszyty Naukowe Uniwersytetu Rzeszowskiego. Seria Socjologiczno-Historyczna (2003), 12 (Historia, 1): 51-58.

${ }^{18}$ Olszański, „Krakowski ‘Czas' wobec powstania”, 198.

${ }^{19}$ Kazimierz Olszański, Prasa galicyjska wobec Powstania Styczniowego, (Prace Komisji Nauk Historycznych PAN, nr 35), (Wrocław, 1975), 23-24.
} 
niesprawdzone lub mogą być nieprawdziwe, dlatego też drukując relacje korespondentów albo używał trybu przypuszczającego albo wprost oświadczał o braku możliwości potwierdzenia opisywanych wydarzeń ${ }^{20}$. Dzięki takiej postawie członków redakcji gazeta zyskała sobie uznanie w szerszych niż dotąd kręgach społeczeństwa oraz wydatnie przyczyniła się do nagłośnienia sprawy polskiej w Europie. W redakcji Czasu długo wierzono i przekonywano czytelników o rychłej interwencji zachodnich mocarstw, zwłaszcza Francji i Austrii, na rzecz uciemiężonego przez cara narodu polskiego, nie tylko na drodze dyplomatycznych zabiegów, ale także dozbrajania powstania i konkretnych działań militarnych. Nadzieje te szybko jednak okazały się płonne, bowiem żadne $\mathrm{z}$ państw nie dążyło do zbrojnej konfrontacji z Rosją, a Petersburg zdecydowanie odrzucił interwencje dyplomatyczne. W zaistniałej sytuacji na łamach Czasu pisano z rezygnacją: „na interweniujących mocarstwach ciąży wstyd niemocy, nieudolności i upokorzenia" ${ }^{21}$. Goryczy dopełniło postępowanie Austrii, która oficjalnie dołączyła do interwencji państw zachodnich, faktycznie jednak władze zastosowały wiele form represji wobec mieszkańców Galicji, podejrzewanych o sprzyjanie powstaniu. Czas na bieżąco informował opinię publiczną o tych wydarzeniach, przedrukowując m.in. listy z nazwiskami aresztowanych czy skazanych przez sądy.

Postawa redaktorów Czasu spotkała się ze zdecydowanym przeciwdziałaniem władz Galicji. Oprócz cenzurowania artykułów, w siedzibie redakcji wielokrotnie dochodziło do rewizji i konfiskat całych numerów dziennika oraz materiałów prasowych, a kilkanaście artykułów zaskarżono przez prokuratorię $^{22}$. Od 8 XI 1863 do 31 III 1864 r. w ogóle zawieszono wydawanie gazety, chociaż tak naprawdę ukazywała się ona prawie w tym samym kształcie, tylko pod zmienionym tytułem, jako Chwila. Oprócz tego redakcja miała 6 procesów, w większości zakończonych karami pieniężnymi, jednak w wyniku jednego z nich w listopadzie 1864 r. na kary więzienia, za zakłócanie „spokojności publicznej”, skazano czterech redaktorów ${ }^{23}$. Sytuację dziennika i w ogóle prasy galicyjskiej zmieniło diametralnie wprowadzenie 29 II 1864 r. stanu oblężenia w Galicji. Redakcji zabroniono krytykować postępowanie Rosji, a informacje o bitwach i potyczkach nakazano zamieszczać

\footnotetext{
${ }^{20}$ Adrian Uljasz, „Krakowski 'Czas' wobec wybuchu i pierwszych tygodni powstania styczniowego. Studium historyczno-prasoznawcze”, w: Galicja a powstanie styczniowe, red. Mariola Hoszowska, Agnieszka Kawalec, Leonida Zaszkilniak (Warszawa-Rzeszów: DiG, 2013), 49.

${ }^{21}$ Olszański, „Krakowski 'Czas' wobec powstania”, 270.

${ }^{22}$ Irena Homola, „Prasa galicyjska w latach 1831-1866”, w: Historia prasy polskiej. Prasa polska 1661-1864, red. Jerzy Łojek (Warszawa: PWN, PAN IBL, 1976), 244.

${ }^{23}$ Bańdo, „Krakowski ‘Czas' (1848-1939)”, 88-89.
} 
tylko zgodnie z urzędowymi sprawozdaniami rosyjskimi. Na skutek zaostrzonej cenzury Czas przedrukowywał zatem artykuły z prasy rosyjskiej i austriackiej, wystrzegając się ich głębszej analizy i komentarzy ${ }^{24}$.

Dawny ton i ostrość wypowiedzi dziennika, nie bez konsekwencji dla jego redaktorów, o czym wspomniano powyżej, powrócił jednak wraz z nową falą represji władz rosyjskich wobec mieszkańców Królestwa Polskiego w końcowej fazie powstania i po jego stłumieniu. Wiele rozpisywano się w dzienniku o prześladowaniu duchowieństwa ${ }^{25}$. O pierwszych represjach wobec klasztorów i zakonników Czas poinformował jeszcze na początku września 1863 r., kiedy w Warszawie aresztowano kleryków franciszkańskich za niezdjęcie czapek przed wielką księżną Aleksandrą, żoną wielkiego księcia Konstantego Mikołajewicza, namiestnika Królestwa, a potem dwóch zakonników franciszkańskich, z których jeden nie spodobał się księżnej ${ }^{26}$. Kilka dni później miała miejsce rewizja w warszawskim klasztorze pijarów ${ }^{27}$, a następnie u misjonarzy ${ }^{28}$. W ich wyniku budynki klasztorne zostały zajęte przez wojska rosyjskie z przeznaczeniem na koszary; taki sam los spotka1 także tamtejsze klasztory bernardynów, kapucynów i karmelitów ${ }^{29}$. Stacjonujące po klasztorach oddziały żołnierzy starały się uprzykrzyć życie zakonników drobnymi, aczkolwiek dotkliwymi szykanami, które w Czasie szczegółowo relacjonowano. Pisano w dzienniku, np. o skardze przeora dominikanów warszawskich na żołnierzy rosyjskich, sprowadzających do klasztoru prostytutki, czy żalach misjonarzy, którym uniemożliwiono normalne odprawianie modłów i nabożeństw w oratorium w kościele, ponieważ właśnie tam rozlokował się oddział żołnierzy. Donoszono także, że żołdacy nie wpuszczali zakonników na obiad do refektarza, dopóki ten zupełnie nie wystygł (niestety nie podano, w którym klasztorze miało to miejsce). Czas informował również o zamienianiu budynków klasztornych na więzienia, np. na początku października 1863 r. przeniesiono więźniów do klasztoru bernardynów w Radomiu i uwięziono przy okazji kilku ojców, na czele z gwardianem Telesforem Zaborkiem. Jeszcze na początku listopada 1863 r. krakowski dziennik ujawnił, że namiestnik Królestwa Polskiego, generał Fiodor (Teodor) Berg zażądał od władz kościelnych, aby dla skazanych uczestników

\footnotetext{
${ }^{24}$ Olszański, „Krakowski ‘Czas’ wobec powstania”, 280

${ }^{25}$ Uljasz, ,Krakowski 'Czas' wobec wybuchu”, 51.

${ }^{26}$ Czas (4 IX 1863), 201: 2; (5 IX 1863), 202: 1.

${ }^{27}$ Czas (10 IX 1863), 205: 1.

${ }^{28}$ Czas (26 IX 1863), 219: 2.

${ }^{29}$ Czas (27 IX 1863), 220: 2.
} 
powstania wyznaczono do przygotowania na śmierć kapłanów z innego niż dotychczas zakonu, czyli kapucynów, gdyż ci źle wypełniają tę posługę i skazani nie okazują strachu przed śmierciąa ${ }^{30}$ Na łamach Czasu ubolewano też nad sytuacją, w jakiej znaleźli się wierni, których nie dopuszczano do zakonników, przez co byli oni pozbawieni posługi sakramentalnej. $Z$ drugiej strony szykanowano w ten sposób duchowieństwo zakonne, odcinając je od ważnego źródła dochodów, równocześnie nakładając na nie wysokie kary pieniężne. Uskarżali się na to np. augustianie w Warszawie, których w lutym 1864 r. skazano na karę wynoszącą 300 rubli za przekazanie powstańczemu Rządowi Narodowemu 1000 złp, a za jej niezapłacenie zatrzymano $\mathrm{w}$ areszcie domowym, dopóki nie uregulują należności ${ }^{31}$ (uiścili ją w kwiet$\mathrm{niu}^{32}$ ). Z kolei warszawscy dominikanie musieli zapłacić karę w tej samej wysokości za niedzielne kazanie, które nie spodobało się dowódcy załogi klasztornej ${ }^{33}$.

Na podstawie korespondencji z Warszawy w połowie lutego 1864 r. Czas (ukazujący się pt. Chwila) doniósł, że władze rosyjskie wydały nakaz opuszczenia przez zakonników klasztoru bernardynów i seminarium księży misjonarzy przy kościele św. Krzyża w Warszawie, z powodu przeznaczenia ich na więzienia polityczne. Zakonnicy zadecydowali, że pozostaną jednak na miejscu, a ustąpią jedynie przed siłą ${ }^{34}$. Doświadczali za to przez kilka miesięcy różnorakich form represji: nagłych rewizji, plądrowania cel, niszczenia sprzętów, znieważania trumien pochowanych w ich kościołach osób, czy nawet kilkakrotnego przekopywania ogródka. Podrzucano im też podczas owych rewizji zawiniątka z bronią, prochem, nabojami czy odezwy Rządu Narodowego. Represje te przybrały jeszcze bardziej na sile po odmówieniu przez nich podpisania wiernopoddańczego adresu do cara ${ }^{35}$. Sprawa zabrania bernardynom i misjonarzom klasztorów znalazła swój oddźwięk w Europie, ale ponieważ nie została sfinalizowana, niektóre gazety, np. prorosyjski warszawski Dziennik Powszechny, szydziły z tych, którzy tę informację kolportowali, jako z prowokatorów. Równocześnie gazeta warszawska $\mathrm{z}$ aprobatą donosiła o spodziewanym odebraniu kapucynom klasztoru w Lublinie, za

\footnotetext{
${ }^{30}$ Czas (5 XII 1863), 297: 2. Nie wiadomo czy rzeczywiście taka była podstawa decyzji Berga, czy raczej należy w tym doszukiwać się ironicznej interpretacji zarządzenia namiestnika przez redakcję gazety.

${ }^{31}$ Chwila (6 II 1864), 29: 2.

${ }^{32}$ Czas (10 IV 1864), 8: 2.

${ }^{33}$ Chwila (9 II 1864), 31: 2 .

${ }^{34}$ Chwila (17 II 1864), 38: 3.

${ }^{35}$ Chwila (19 II 1864), 40: 1.
} 
znalezienie u nich podczas rewizji kompromitujących papierów „rządu podziemnego", broni i tajnej drukarni ${ }^{36}$. Surowe represje dotknęly także, o czym szczegółowo doniesiono w Czasie, klasztor należący do kapucynów w Lądzie w powiecie konińskim. Po wkroczeniu tam 28 VI 1864 r. wojska rosyjskiego, klasztor skasowano, wszystkich zakonników, na czele z gwardianem Emilianem Ołtarzewskim, aresztowano a następnie zesłano na Syberię ${ }^{37}$. Była to kara za ukrywanie współbrata o. Maksymiliana (Maxa) Tarejwo, kapelana oddziału gen. Edmunda Taczanowskiego i płomiennego kaznodziei patriotycznego, powieszonego 19 VII tego roku $^{38}$. Nie był to pierwszy zakonnik stracony za udział $\mathrm{w}$ powstaniu. W krakowskim dzienniku już na początku stycznia 1864 r. przedrukowano za Dziennikiem Poznańskim listę 204 osób zgładzonych przez Rosjan, wśród których było kilku księży katolickich, w tym kapucyn, o. Agrypin Konarski (Piotr Paweł Konarski), kapelan oddziałów polskich i czynny uczestnik walk zbrojnych, powieszony 12 VI 1863 r. na stokach Cytadeli warszawskiej, w obecności spowiednika o. Honorata Koźmińskiego ${ }^{39}$. Podobną listę duchownych z Królestwa wywiezionych na Sybir, skazanych na ciężkie roboty, wychłostanych lub straconych, wśród których było ponad 20 zakonników (głównie reformatów, kapucynów i bernardynów) Czas opublikował w lipcu 1864 r. $^{40}$.

Represje ze strony władz carskich dotykały także klasztory żeńskie. Chociaż, na skutek stanowczej interwencji władz kościelnych u Berga, zaniechano tymczasowo zakwaterowania wojska w klasztorach żeńskich, to jednak nie omijały zakonnic różne przykrości, w tym nagłe rewizje, jak to dwukrotnie miało miejsce $\mathrm{w}$ klasztorze felicjanek $\mathrm{w}$ Warszawie $^{41}$, a nawet $\mathrm{w}$ miejscu publicznym, na dworcu, gdzie żołnierze w obecności oficerów przeszukali dwie siostry miłosierdzia ${ }^{42}$. Krakowski dziennik szczegółowo zrelacjonował także jak felicjanki represjonowano jesienią 1863 r. Kilkadziesiąt zakonnic zostało wówczas praktycznie uwięzionych w klasztorze warszawskim, do którego zjechały z różnych stron kraju na coroczne rekolekcje zakonne. Odmówiono im bowiem wydania paszportów na drogę powrotną, uzasadniając

${ }^{36}$ Chwila (25 II 1864), 45: 3.

${ }^{37}$ Czas (26 VII 1864), 95: 1; Roland Prejs, Zakonnicy franciszkańscy Królestwa Polskiego po kasacie 1864 roku. Dzieje-postawy (Warszawa-Sandomierz: Bracia Mniejsi Kapucyni, Wydawnictwo Diecezjalne, 2003), 87.

${ }^{38}$ Czas (19 VII 1864), 89: 1; (31 VII 1864), 100: 2.

${ }^{39}$ Chwila (30 I 1864), 24: 3.

${ }^{40}$ Czas (8 VII 1864), 80: 2.

${ }^{41}$ Czas (7 X 1863), 228: 2.

${ }^{42}$ Chwila (26 II 1864), 46: 2. 
odmowę tym, że na prowincji, pod pozorem pracy opiekuńczo-wychowawczej, pielęgnują rannych powstańców, a zbierając jałmużnę w rzeczywistości kwestują na rzecz powstania i kolportują nielegalne pisma. Nie pomogła interwencja władz kościelnych w tej sprawie u samego namiestnika, który na wieść o widmie głodu w klasztorze (nie był on przygotowany na utrzymanie tak dużej liczby zakonnic przez dłuższy czas), z własnej kieszeni, jak zaznaczył, dał 1000 złp, które jednak kazał sobie zwrócić, gdy Rada Administracyjna wyasygnowała z funduszu duchownego 4000 złp na wsparcie sióstr ${ }^{43}$.

Dnia 25 III 1864 r. krakowski dziennik po raz pierwszy doniósł, że powszechnie mówi się o zamiarze likwidacji klasztorów przez władze carskie. Informacja była bardzo lakoniczna i znalazła się na przedostatniej stronie wydania, zapewne nie wywołując większych reakcji ${ }^{44}$. Pod koniec maja $1864 \mathrm{r}$. w Czasie $\mathrm{z}$ niedowierzaniem pisano o doniesieniach prasy pruskiej i austriackiej na temat zamiaru cara wyjęcia Kościoła katolickiego w Królestwie, na Litwie i Rusi spod jurysdykcji Rzymu i poddania go pod władzę dwóch synodów: w Petersburgu i w Warszawie, w skład których wchodziłyby także osoby świeckie ${ }^{45}$. Równocześnie na łamach gazety relacjonowano i komentowano nagonkę trwającą od kilku tygodni w prasie rosyjskiej na religię katolicką, polegającą na publikowaniu pseudohistorycznych artykułów rosyjskich uczonych na temat gnębienia przez wieki wyznawców prawosławia przez katolików, odbierania im cerkwi i zamieniania ich, jak np. w Krakowie (sic!), na katolickie klasztory czy też opisywanie przypadków przejścia na prawosławie, często zresztą nie do końca zgodnych z prawdą, bo konwersji dokonywano nierzadko pod przymusem ${ }^{46}$. W połowie lipca $1864 \mathrm{r}$. z Warszawy ponownie nadeszła wiadomość o zapowiedzianym i spodziewanym w najbliższych dniach ukazie o likwidacji w Królestwie Polskim klasztorów żeńskich i męskich. Pomysł ten Czas przypisał sekretarzowi stanu do spraw Królestwa Polskiego, Mikołajowi Aleksiejewiczowi Milutinowi, bratu ministra wojny Rosji, generała Dymitra Milutina, zwolennikowi liberalizmu. Widziano jednak w tym akcie nie tyle element represji popowstaniowych, ale raczej narzędzie walki z katolicyzmem i w ogóle z Kościołem, dlatego wzywano mocarstwa europejskie do zdecydowanej reakcji ${ }^{47}$. Tymczasem w prorosyjskiej prasie, zarówno krajowej, jak i zagranicznej, działania cara

\footnotetext{
${ }^{43}$ Chwila (5 III 1864), 53: 1-2; (13 III 1864), 60: 2.

${ }^{44}$ Chwila (25 III 1864), 70: 3.

${ }^{45}$ Czas (28 V 1864), 46: 1.

${ }^{46}$ Czas (15 V 1864), 37: 2; (3 VII 1864), 76: 1-2.

${ }^{47}$ Czas (16 VII 1864), 87: 3.
} 
przedstawiano jako dążenie do reformy i naprawy Kościoła, a szczególnie jako walkę z ciemnotą i zacofaniem Rzymu, przy równoczesnym zaprzeczaniu jakimkolwiek prześladowaniom religii katolickiej w Rosji ${ }^{48}$. Szczególnie boleśnie przyjęto w Polsce, co wyraźnie zaakcentowano na łamach Czasu, nieprzychylne powstaniu i jego uczestnikom artykuły zamieszczone w L'Osservatore Romano, deprecjonujące liczbę duchownych, którzy wzięli w nim udział, umniejszające zasięg i wydźwięk powstania oraz widzące w nim przyczynę zaniechania przez cara zbawiennych (sic!) reform w Królestwie. Krakowski dziennik starał się jednak usprawiedliwić jednoznaczny wydźwięk tych publikacji, pisząc że mają one na celu nie potępienie powstania, ale jedynie obronę Kościoła przed represjami ${ }^{49}$. Jednakże nieprzychylne stanowisko prasy zachodniej i polskiej z terenu zaboru rosyjskiego, a zwłaszcza Dziennika Warszawskiego, doprowadziło w końcu do ostrej polemiki z redakcją Czasu, dotyczącej już nie tylko spraw polityczno-narodowych, ale także istoty religii oraz pojmowania sakramentów i rozumienia dogmatów ${ }^{50}$. Na początku i w połowie sierpnia 1864 r. Czas po raz kolejny sygnalizował istnienie pogłosek o likwidacji klasztorów w Królestwie Polskim. Opierając się jednak na artykule w Dzienniku Warszawskim (list zewnętrzny) uspokajał, że jakkolwiek w klasztorach istnieją - według władz rosyjskich - nadużycia i rozprężenie obyczajów, to jednak rząd dąży do ich reformy, a nie do całkowitego ich zniesienia ${ }^{51}$. Kilka dni później krakowski dziennik, zainspirowany doniesieniami prasy francuskiej i niemieckiej o możliwości likwidacji klasztorów pod zaborem rosyjskim, znów uspokajał, że chodzi jedynie o ich reformę, ale tym razem odbierał Rosjanom prawo jej dokonania, uznając katolicką zwierzchność kościelną za jedyną władzę upoważnioną do podjęcia takich działań ${ }^{52}$. Niemniej jednak od tego momentu, na łamach gazety, coraz częściej obnażano działania Rosjan zmierzające do poważnych zmian w funkcjonowaniu Kościoła katolickiego w zaborze rosyjskim. Za petersburskim korespondentem berlińskiej Nationale-Zeitung informowano, że w Rosji ukazała się książka pt. Zestawienie przypadków rzymsko katolickiego kościoła za granica, będąca zbiorem dokumentów z XVIII i XIX w., dotyczących stosunków Francji, Hiszpanii, Portugalii, Neapolu, Westfalii i Austrii ze Stolicą Apostolską. W zamiarze wydawców było porównanie położenia

\footnotetext{
${ }^{48}$ Czas (22 VII 1864), 92: 2; (5 VIII 1864), 104: 2.

${ }^{49}$ Czas (8 IX 1864), 132: 2.

${ }^{50}$ Czas (6 VIII 1864), 105: 1-2.

51 Tamże.

${ }^{52}$ Czas (14 VIII 1864), 112: 1.
} 
Kościoła katolickiego w Polsce z sytuacją Kościoła w wymienionych krajach i udowodnienie, że nawet arcychrześcijańscy monarchowie nie mieli żadnych skrupułów, gdy wymagała tego racja stanu, aby zerwać więzi z rzymską hierarchią. Wspomniana książka miała być przeznaczona tylko dla wąskiego grona odbiorców, a jej wydanie było kolejnym krokiem do uzasadnienia zamiaru likwidacji klasztorów katolickich w Rosji ${ }^{53}$. Równocześnie, jak donosił Czas, chcąc ukryć przygotowania do zniesienia klasztorów i uśpić czujność Stolicy Apostolskiej, dyplomacja rosyjska pracowała nad polepszeniem stosunków cara Aleksandra II z papieżem Piusem IX, czego widomym znakiem miał być przyjazd w karnawale do Rzymu carewicza Mikołaja, następcy tronu ${ }^{54}$. Zabiegi te spełzły jednak na niczym, ponieważ 20 IX $1864 \mathrm{r}$. ogłoszono wreszcie w Rzymie gotową już pod koniec lipca encyklikę Maxime quidem, w której co prawda papież wzywał duchowieństwo polskie, na czele z biskupami, do posłuszeństwa władzy rosyjskiej, ale równocześnie nakazywał im nieposłuszeństwo w przypadku sprzeczności prawa ludzkiego z przykazaniami Bożymi oraz zapowiadał kary Boże dla nieprzyjaciół religii katolickiej ${ }^{55}$. Ważnym punktem tego dokumentu było potępienie nadużyć rosyjskich względem duchowieństwa katolickiego i wszelkich kar stosowanych wobec niego przez władze carskie ${ }^{56}$. Encyklika doczekała się wielu komentarzy i spowodowała ponowne zaognienie stosunków między Rosją a Stolicą Apostolską ${ }^{57}$, zwłaszcza, że jakkolwiek papież potępił powstanie styczniowe, to jednak uważał, że rząd carski wykorzystuje je do wyrugowania religii katolickiej ${ }^{58}$. Rosyjskie gazety pisały zjadliwie, że encyklika jest dziełem jezuitów, którzy boją się utracić swą potęgę w Polsce ${ }^{59}$. Czas 20 X 1864 r. zacytował główne tezy artykułu zmieszczonego w Russkom Inwalidie, $\mathrm{w}$ związku $\mathrm{z}$ możliwością zerwania konkordatu między Rosją a Rzymem, w którym podkreślono, że jest już najwyższy czas, aby uniezależnić od papiestwa „łaciństwo w Rosji” ${ }^{60}$.

W drugiej połowie września 1864 r. za prasą francuską podano w Czasie informację o ukazie carskim dotyczącym reformy szkolnictwa w Królestwie ${ }^{61}$,

\footnotetext{
${ }^{53}$ Czas (7 IX 1864), 131: 2.

${ }^{54}$ Czas (13 IX 1864), 135: 1.

${ }^{55}$ Czas (21 IX 1864), 142: 3.

${ }^{56}$ Czas (24 IX 1864), 145: 3; (25 IX 1864), 146: 1.

${ }^{57}$ Czas (25 IX 1864), 146: 1.

${ }^{58}$ Czas (1 X 1864), 151: 2-3.

${ }^{59}$ Czas (5 X 1864), 154: 1.

${ }^{60}$ Czas (20 X 1864), 167: 2.

${ }^{61}$ Czas (24 IX 1864), 145: 3.
} 
a następnie pod koniec miesiąca przedrukowano dokument $\mathrm{w}$ całości ${ }^{62}$. Pierwszym przejawem tej reformy, jak zauważono, stało się podwojenie lekcji języka rosyjskiego i zakładanie nowych szkół dla rzekomo dużej liczby uczniów innych narodowości niż polska. Odłączono także Wydział Religijny od Komisji Oświecenia i włączono do Wydziału Spraw Wewnętrznych $^{63}$. Czas słusznie upatrywał $\mathrm{w}$ tych działaniach nie reform społecznych, ale politycznych, będących wstępem do likwidacji klasztorów. Szczególną uwagę zwrócono na Artykuł 35 wspomnianego ukazu, który wyraźnie mówił, że w szkołach początkowych nauczycielami nie mogą być członkowie męskich i żeńskich zgromadzeń zakonnych ${ }^{64}$. Podkreślono też, że zagraniczna prasa, zwłaszcza francuska, z niedowierzaniem komentowała ten Artykuł, pisząc że zakaz ten nie ma nic wspólnego z głoszonym przez Rosję liberalizmem w oświacie, gdyż dzieci pozbawione nauczania religii, zostaną równocześnie pozbawione moralnej podstawy życia ${ }^{65}$.

O ukazie znoszącym klasztory w Królestwie Polskim z 8 XI 1864 r. Czas poinformował dopiero $23 \mathrm{XI}$ tego roku na podstawie depesz telegraficznych z Wiednia i Berlina. Doniesiono wówczas, że dekret otrzymał już sankcję cesarską (car z rodziną znajdował się wówczas w kilkutygodniowej podróży po Europie). Klasztory, które brały udział w powstaniu styczniowym, miały być całkowicie zlikwidowane, pozostałe poddane pod nadzór rządu. Redakcja Czasu przytomnie zauważyła, że nie ma już w Królestwie klasztorów, które brały udział w powstaniu, gdyż nawet tylko te, które udzielały powstańcom schronienia, zostały zamienione na więzienia lub koszary, a zakonnicy wywiezieni ${ }^{66}$. Kilka dni później (29 i 30 XI) za Russkim Inwalidom na łamach Czasu donoszono o ogłoszeniu ukazu carskiego likwidującego klasztory żeńskie i męskie liczące mniej niż ośmiu członków, ze względu na przepisy kanoniczne, podobnie jak klasztory biorące czynny udział w powstaniu. Członkowie tychże zgromadzeń mogli wstępować do liczniejszych klasztorów albo otrzymać ze skarbu państwa fundusze na wyjazd za granicę. Ukaz zawierał również postanowienia dotyczące szkół i zakładów opiekuńczych prowadzonych przez zakonników i zakonnice oraz majątków klasztornych. Szkoły miały przejść pod zarząd Komisji Administracyjnej Wychowania Ludu, placówki opiekuńcze pod Komisje Zarządu Wewnętrznego, zaś

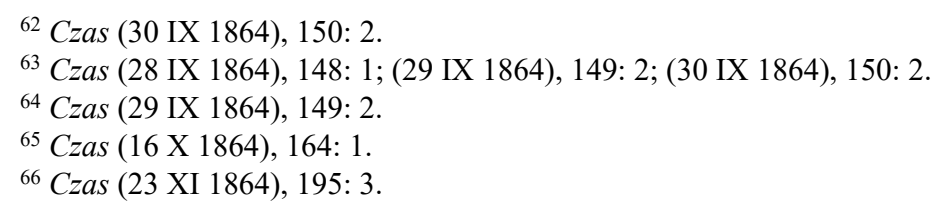


majątki klasztorne zostały przeznaczone wyłącznie na funkcjonowanie tych instytucji oraz na cele kościelne. Służba Boża w kościołach skasowanych klasztorów miała być nadal prowadzona. Pozostałym klasztorom zabroniono kontaktów z ich władzami zakonnymi (generałami i prowincjałami), poddając je naczelnej władzy kościelnej ${ }^{67}$. Doniesienia te zostały w Czasie szeroko skomentowane. Przewidywano, że likwidacji ulegną także klasztory na razie pozostawione, po pierwsze z racji niemożności utrzymania zbyt dużej wspólnoty zakonnej, zasilonej zakonnikami ze skasowanych klasztorów, po drugie z powodu zamknięcia ich nowicjatów. Za ogromnie perfidne działanie rządu carskiego uważano uzasadnianie kasaty klasztorów przepisami kanonicznymi. Porównując to wydarzenie do wydarzeń rewolucji francuskiej ubolewano, że ukaz carski godzi: „w życie narodu religijne, obyczajowe, cywilizacyjne, w jego najpiękniejsze instytucje kościelne, edukacyjne, w jego tradycye i pamiątki, w jego środki intelektualne i zasoby materyalne, w jego ekonomiczne stosunki”, poza tym uderza nie tylko w naród polski, ale także w papieża i jest odpowiedzią na jego ostatnią encyklikę ${ }^{68}$. Krakowska gazeta, pod koniec listopada, ujawniła także szczegóły wprowadzenia ukazu w życie, według starannie przygotowanego planu mającego zapobiec wszelkiemu oporowi ${ }^{69}$.

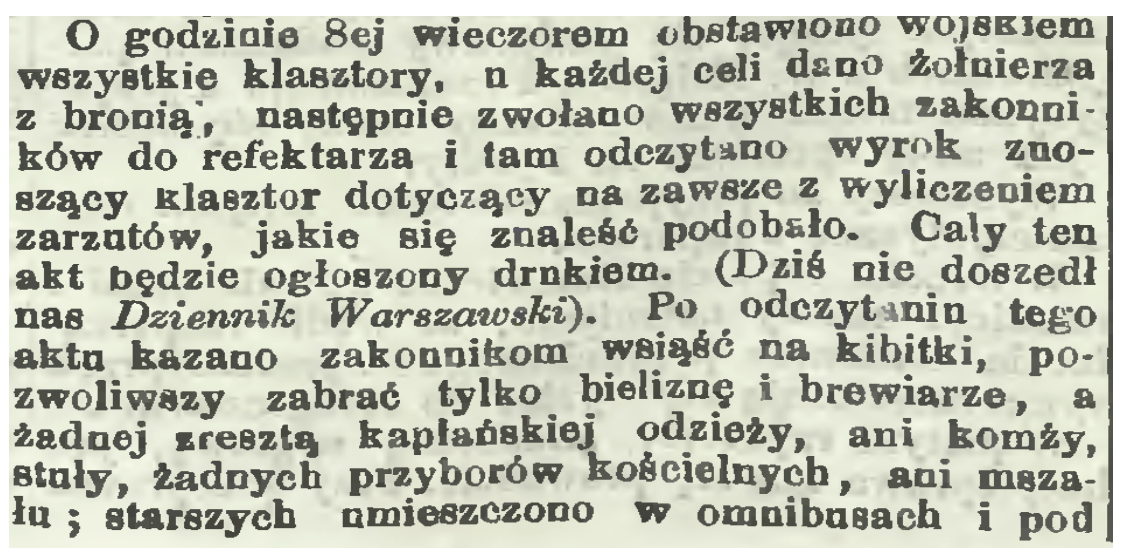

\footnotetext{
${ }^{67}$ Czas (29 XI 1864), 200: 3; (30 XI 1864), 201: 4.

${ }^{68}$ Czas (30 XI 1864), 201: 1.

${ }^{69}$ Czas (30 XI 1864), 201: 4.
} 


\begin{abstract}
gilną eakorta wywieziono wezystkich na Prage. Kapucyai, Beruardyni, Refurmaci, Domioikanio, Franciezkanie, Karmelici, Angabtyanie, Tryoitarze (ntrzymujacy dom cbłakanych), Misyonarze, a $z$ tych ostatnich zostawiono przy kosciele Swietego Krzyźa siedmia ksiezy mazalnych i dziesecin klerykớ; przy innych kościołach po dwóch zakonnikow, Gdyz Sakramenta są jeszcze po kosciolach, lecz po wywiezieniu Sakramentón po zostali zakonniey będa takzo wyguani. Wszystkio celc zapieczętowano, kosciuly pozostaly bez slaźby Bozej. W mieście byl nazajutrz rano placz glófay, po kósciolauh klegczalo i lezalo krzyzem wiele osob. Kapacynow wywozg do Zakroczymia, wieln innyan pozwolono przywdziae snknio. swieckie, sekulargzować się lab wyjezdźsć za granice, obiecnjąs dac im raz na zawazo odozepnego po sto rubli. Nie miano względa na chorjch, bo i takich wywizono. Dzis wezyscy biegna na Pra. ge zeguać wjgnańców. W catem Królestwie ma być zaiesiony ih 90 klasztorów, a zostanie 50 , w Warszawio zaś ma bjé tylko 5 kosoiotón pa. rafialnych. Z zakonami zehskiemi nie inaczej sie dzieje: zaczęto od Felicyanek. Wielo kościolów bedzie zamkniegtych i przezaaczonych na cole \& ckie, inne zxmionione moke na cerkwie. Tak przynajmniej glos publiczuy sio trwoky. Z Pragi wywieziono zaraz okolo 600 księj, z tych 200 za granice, wielkg liczbo koleją do Poteraburga. Bogg pie dokgd stamtad.
\end{abstract}

Il. 1. Fragment wydania Czasu, nr 201 z 30 XI 1864 r.

Jak informował Czas, zamknięto łącznie 74 klasztory męskie i 4 żeńskie z powodu niewystarczającej liczby członków oraz 39 za udział w powstaniu, czyli łącznie 127 (w rzeczywistości ze 197 klasztorów istniejących w Królestwie zniesiono 110 klasztorów, 35 uznano za etatowe, a pozostałe za nieetatowe, czyli w praktyce także podlegające w niedługim czasie likwidacji. Z 2189 zakonników i zakonnic mniej niż połowa otrzymała prawo do dalszego prowadzenia życia zakonnego ${ }^{70}$ ). Doniesiono również, że Warszawa jest

\footnotetext{
${ }^{70}$ Zygmunt Zieliński, „Kościół ery popowstaniowej wobec nowych problemów. Powstanie styczniowe - sprawy, regiony, ludzie", Annales Universitatis Mariae Curie-Skłodowska ( 1993), 48, 4 (Historia): 33.
} 
spokojna, czyli że mimo tragicznych wydarzeń nie doszło do żadnych wystąpień i utarczek wojsk rosyjskich z miejscową ludnością.

Pełny tekst ukazu kasacyjnego, wraz z dodatkowymi przepisami, redakcja dziennika otrzymała 1 XII 1864 r., a opublikowała go ze wszystkimi dodatkami w dniu następnym ${ }^{71}$. Szczególnie podkreślano niesprawiedliwość, jaka dotknęła warszawskich misjonarzy, których skasowano - według Czasu tylko za to, że przez dom, będący ich własnością, przebiegł jeden z uczestników zamachu (19 IX 1863 r.) na namiestnika Berga ${ }^{72}$. Z goryczą relacjonowano na łamach Czasu pełne zarzutów wobec zakonników ze skasowanych klasztorów artykuły w Dzienniku Warszawskim ${ }^{73}$. W kolejnych dniach przedrukowano przepisy dodatkowe do $\mathrm{ukazu}^{74}$, zawierające uszczegółowienie aktu sekularyzacji. W obliczu zaistniałej sytuacji ogromnej wagi nabrało ogłoszenie przez Czas, za florenckim dziennikiem La Nazione (przez redakcję określanym jako pismo starozakonnych), spodziewanej w czerwcu 1865 r. kanonizacji bł. Jozafata Kuncewicza ${ }^{75}$, którą to wiadomość włoska gazeta jednakże dość nieprzychylnie skomentowała pisząc, że „o tym zapomnianym Polaku w Rzymie pewnie nadal by nie pamiętano, gdyby papież nie potrzebował łatkę przypiąć Rosyi i podnieść religijne namiętności tych poczciwych Polaków"76.

Jednym ze skutków kasaty klasztorów w Królestwie Polskim, o czym doniósł Czas na początku grudnia 1864 r., było odwołanie zapowiadanej dużo wcześniej wizyty w Rzymie, przebywającego w Nicei carewicza Mikołaja. Strona rosyjska, jak komentował krakowski dziennik, obawiała się zapewne, że podczas nieuchronnego spotkania z papieżem, carewicz mógłby usłyszeć prośby i groźby odnośnie do sprawy polskiej, podobne do tych, które usłyszał jego dziad, car Mikołaj I z ust papieża Grzegorza XVI, a na które nie umiałby i nie chciał odpowiedzieć 77 . Kilka dni później Czas potwierdził, że do spotkania nie dojdzie, ponieważ papież nie zgodził się na warunek Rosjan niewspominania o Polsce ${ }^{78}$. W wydaniu z 4 XII 1864 r. przekazano, na podstawie prywatnej korespondencji z Warszawy sprzed kilku dni, dalsze szczegóły

${ }^{71}$ Czas (1 XII 1864), 202: 3; (2 XII 1864), 203: 2-3.

${ }^{72}$ Czas (1 XII 1864), 202: 3; (2 XII 1864), 203: 3.

${ }^{73}$ Czas (1 XII 1864), 202: 3.

${ }^{74}$ Czas (3 XII 1864), 204: 2; (4 XII 1864), 205: 3.

${ }^{75}$ Kanonizacja bł. Jozafata Kuncewicza miała miejsce dopiero 29 VI 1867 r.

${ }^{76}$ Czas (3 XII 1864), 204: 1.

${ }^{77}$ Czas (4 XII 1864), 205: 2. Do spotkania zapewne nie doszło głównie z powodu ciężkiej choroby carewicza, która wkrótce doprowadziła do jego zgonu.

${ }^{78}$ Czas (7 XII 1864), 207: 1. 
dotyczące likwidacji klasztorów i losów wypędzonych zakonników. Czas poinformował, że dotychczas nie ruszono klasztorów żeńskich, ale że w każdej chwili spodziewają się one zamknięcia, podobnie jak wszelkie bractwa religijne i tercjarze, oraz że prowadzone przez zakonników zakłady dobroczynne przechodzą pod administrację rządową, co redakcja sarkastycznie skomentowała: „Uczynki miłosierdzia wykonywane z urzędu - to czysta parodya miłości bliźniego"79. Z obawą pisano także o tajnych rozporządzeniach, które przywiózł do Warszawy Mikołaj Milutin, dotyczących zamiany kościołów katolickich na cerkwie, opatrując doniesienia patetycznym komentarzem: „Schizma w przedsionku - nadzieja tylko w Bogu i w poczuciu własnej godności a wytrwałości w wierze i uczuciu narodowem”. Opisano również różne postawy warszawiaków wobec ostatnich wydarzeń: kiedy jedni biegli do klasztorów i starali się nieść pociechę zakonnikom, inni, jak np. niektóre pobożne damy polskie, mające nawet klęczniki w swych buduarach, pląsały wówczas na balu u namiestnika, niezupełnie przymusowo ${ }^{80}$. Nie omieszkano przy tej okazji pokazać jak na likwidację klasztorów w Królestwie zareagowano w Galicji. W części literacko-artystycznej wydania Czasu z 8 XII 1864 r. zamieszczono emocjonalny artykuł, opisujący zachowanie ludzi podczas towarzyskiego spotkania. Kiedy doszła ich wieść o kasatach, siedzieli w milczeniu z pochylonymi głowami, niektórzy płakali, gdyż: „Nienawiść schyzmatycka przystrojona w wypłowiały jakobinizm zaprowadza dziwny porządek w dziele dziewięciowiekowej cywilizacji”"81.

W krakowskim dzienniku starano się także opisać, unikając komentarzy, każdy przypadek represji ze strony władz austriackich względem zakonników z Galicji zaangażowanych w powstanie. W dziale „Kronika miejscowa i zagraniczna" już 10 I 1864 r. redakcja Chwili umieściła krótką notkę o skazaniu przez władze austriackie w Krakowie na rok więzienia za udział w powstaniu, trzymanego przez 10 miesięcy na zamku wawelskim reformata o. Alojzego Chojnackiego (Euzebiusza Teofila Chojnackiego h. Trzaska), uczestnika walk zbrojnych w stopniu kapitana i werbownika ochotników do powstania $^{82}$. Z kolei 29 I tego roku poinformowano o rewizji o godzinie 6.30 rano w krakowskim klasztorze bonifratrów, gdzie zapewne poszukiwano broni lub ukrywających się osób ${ }^{83}$. Krakowscy zakonnicy, zwłaszcza reformaci

\footnotetext{
${ }^{79}$ Czas (4 XII 1864), 205: 3.

${ }^{80}$ Tamże.

${ }^{81}$ Czas (8 XII 1864), 208: 1.

${ }^{82}$ Chwila (10 I 1864), 7: 3.

${ }^{83}$ Chwila (29 I 1864), 23: 3.
} 
i kapucyni, angażowali się w powstanie także duchowo, poprzez odprawianie modłów i mszy za dusze poległych czy organizowanie kwesty na rzecz zesłańców ${ }^{84}$; w tego typu działalność władze austriackie jednak nie ingerowały. Likwidacja klasztorów w Królestwie oraz pozbawianie placówek zakonnych majątków i dochodów miały jednakże wpływ na kondycję finansową domów zakonnych, istniejących co prawda na ziemiach znajdujących się pod innymi zaborami, ale często funkcjonujących w ramach jednej prowincji. Stąd też 8 XII 1864 r. zamieszczono w Czasie dramatyczny apel o pomoc, w imieniu krakowskich kapucynów, którzy po skasowaniu klasztoru warszawskiego cierpieli biedę, utrzymując się tylko z legatu wynoszącego 200 złp (konwent liczył wówczas czterech ojców i ośmiu braci) ${ }^{85}$.

W dniach 6-10 XII 1864 r. Czas przedrukował raport specjalnej Komisji Administracyjnej, na czele której stanął książę Władimir Czerkaski. Komisja została powołana w Warszawie rozkazem cara Aleksandra II jeszcze w czerwcu tego roku, a jej celem było zbadanie, w oparciu o zebraną dokumentację, skali i zasięgu udziału klasztorów oraz poszczególnych zakonników w powstaniu, wykazanie im przewinień i zbrodniczej działalności, także przed wybuchem powstania oraz przedstawienie obecnego położenia klasztorów w Królestwie Polskim. Raport Komisji stał się podstawą do likwidacji klasztorów, bowiem w jego podsumowaniu znalazło się sformułowanie mówiące o tym, że klasztory były jednym z głównych narzędzi rewolucji i w powstaniu brały różny, ale znaczący udział. Dodano również, że nowożytna cywilizacja spowodowała rozprężenie moralne wśród zakonników a buntownicze działania obnażyły zło społeczne powstałe w klasztorach, dlatego wymagają one szybkiego wyleczenia ${ }^{86}$. Analiza tego dokumentu przez redakcję Czasu pozwoliła na wykazanie wielu w nim błędów, jak np. tego, że na pogrzebie wdowy po obrońcy Woli w 1831 r., generałowej Katarzyny ze Schroederów Sowińskiej, który odbył się 11 VI 1860 r. i przerodził w wielką manifestację patriotyczną, kazanie wygłosił zakonnik - reformat, podczas gdy zmarła była wyznania kalwińskiego, została pochowana na cmentarzu protestanckim i kazanie wygłosił ksiądz reformowany ${ }^{87}$.

${ }^{84}$ Chwila (6 II 1864), 29: 3; (18 II 1864), 39: 3.

${ }^{85}$ Czas (8 XII 1864), 208: 3.

${ }^{86}$ Czas (6 XII 1864), 206: 2; (7 XII 1864), 207: 2-3; (8 XII 1864), 208: 2; (10 XII 1864), 209: 2.

${ }^{87}$ Czas (7 XII 1864), 207: 3; Jan Skarbek, „Katarzyna Antonina Sowińska ze Schroederów, 1.v. Jonasowa (1776-1860), działaczka społeczna i charytatywna", w: Polski Stownik Biograficzny, t. 40, z. 167, red. Andrzej Romanowski (Warszawa-Kraków, 2001), 632-633. 
Jak donoszono w krakowskiej gazecie 11 XII 1864 r., na podstawie informacji z Dziennika Warszawskiego, w Warszawie rozpuszczano pogłoski o kolejnych zamierzeniach rządu rosyjskiego względem klasztorów, tj. o oddawaniu kościołów klasztornych Żydom lub prawosławnym, o zburzeniu kościoła kapucynów, o pobieraniu opłat za wstęp do kościołów oraz o wprowadzeniu stawki za chrzest wynoszącej 10 rubli. Miały one na celu podburzyć ludność przeciwko władzy rosyjskiej, ale wszystkie były dementowane przez organy rządowe. Trudno jednak dziwić się ludziom, jak stwierdzono w redakcji Czasu, że dawali im wiarę wobec ostatnich wydarzeń w Królestwie oraz przymusowego nawracania katolików na Litwie na prawosławie. Tenże Dziennik Warszawski w korespondencji ze Lwowa pochwalał zresztą kasatę klasztorów katolickich, za słuszne uważał opróżnianie klasztornych kościołów z wszystkich cennych rzeczy, które przecież nie do zakonników należały, a także wydrukował przemowę Berga do przełożonych nieskasowanych klasztorów, których wezwał do siebie, pouczał o ich obowiązkach oraz wytykał im błędy i uchybienia ${ }^{88}$.

W tydzień później Czas ponownie, za Dziennikiem Warszawskim, poinformował o zniesieniu $\mathrm{z}$ powodów kanonicznych wspominanych już 4 klasztorów żeńskich w Królestwie Polskim, na 21 istniejących (nie licząc ponad 20 zgromadzeń sióstr miłosierdzia). Były to mariawitki w Częstochowie, norbertanki w Pińczowie oraz brygidki i karmelitanki w Lublinie. Mariawitkom, uważanym za kongregację, zezwolono powrócić do rodzinnych domów lub miały być przeniesione do dominikanek do Piotrkowa, norbertanki zamierzano umieścić $\mathrm{w}$ klasztorze tego zakonu w Imbramowicach, natomiast karmelitankom i brygidkom zezwolono wybrać sobie któryś z pozostawionych klasztorów lubelskich ${ }^{89}$. Zaznaczono też, że w Warszawie istnieje dom felicjanek nieposiadający rządowego zatwierdzenia i wobec niego prowadzone jest osobne śledztwo ${ }^{90}$. Niedługo potem Czas doniósł jednak, że dekret likwidujący felicjanki, jako zgromadzenie nielegalne, a przy tym zaangażowane w działalność powstańczą, Berg podpisał już 16 XII 1864 r. ze skutkiem natychmiastowym i jego realizacja już się rozpoczęła. W tym samym wydaniu redakcja poinformowała także o zniesieniu przez namiestnika

\footnotetext{
${ }^{88}$ Czas (11 XII 1864), 210: 2.

${ }^{89} \mathrm{~W}$ rzeczywistości skasowano wówczas tylko klasztor mariawitek, bowiem oba wspomniane klasztory lubelskie zlikwidowano jeszcze w latach 1818-1819, ale nie usunięto z nich zakonnic, pozwalając zostać im na miejscu do śmierci, natomiast norbertanki przeniesiono z Pińczowa do klasztoru w Imbramowicach już w kwietniu 1864 r. Zob. Piotr Paweł Gach, Kasaty zakonów na ziemiach dawnej Rzeczypospolitej i Śląska 1773-1914 (Lublin: Redakcja Wydawnictw KUL, 1984), 182.

${ }^{90}$ Czas (18 XII 1864), 216: 3.
} 
w imieniu cara, dekretem z 10 XII 1864 r., czterech z pięciu istniejących w Królestwie klasztorów bazylianów. Oba dokumenty zostały w krakowskim dzienniku w całości wydrukowane, ale bez żadnego komentarza ${ }^{91}$.

Czas informował na bieżąco o reakcjach opinii publicznej za granicą na wiadomość o zniesieniu klasztorów w Królestwie, na podstawie artykułów w czołowych gazetach i relacji własnych korespondentów. Komentował też te reakcje na własny sposób. W krakowskim dzienniku zamieszczono obszerne, niezmiernie emfatyczne wyjątki z artykułów drukowanych w $L a$ Correspondance de Rome, w których donoszono o ponurych nastrojach panujących wśród członków rzymskiej arystokracji, ale bardziej z powodu prześladowania Kościoła powszechnego i religii katolickiej, niż użalania się nad Polakami ${ }^{92}$.

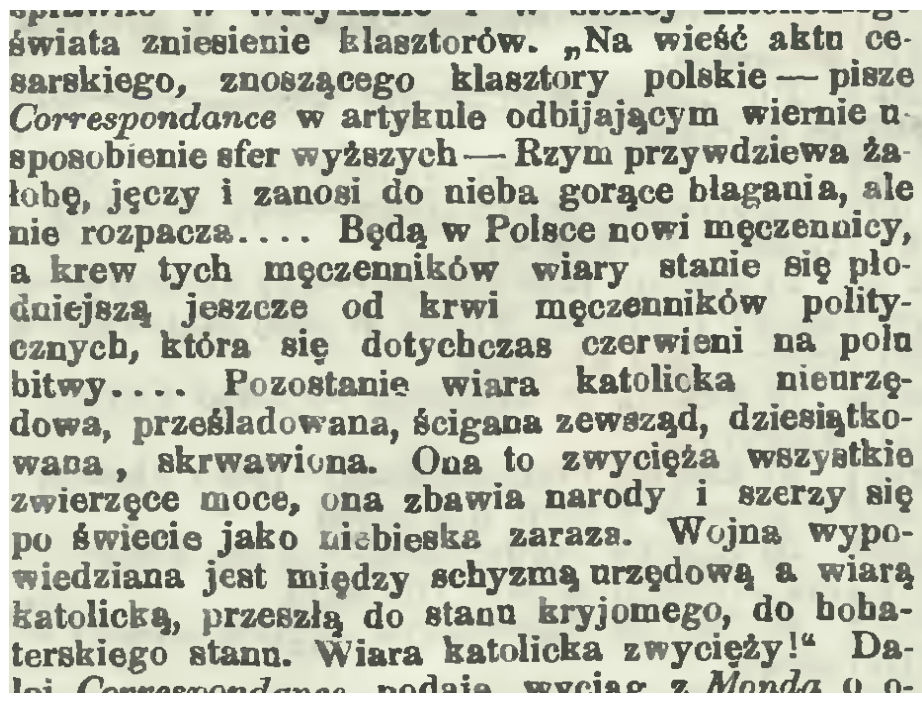

Il. 2. Fragment wydania Czasu, nr 223 z 28 XII 1864 r.

Podano również informację, że rzymski dziennik Il Progresso sociale podejrzewał, iż cała akcja ze zniesieniem klasztorów ma na celu zmuszenie Polaków do wystosowania adresu do cara z prośbą o włączenie Królestwa Polskiego do Rosji ${ }^{93}$. Równocześnie Czas informował, że londyński Times, raczej nieprzychylny katolicyzmowi, pisał, że jakkolwiek ostatnie wydarzenia

\footnotetext{
${ }^{91}$ Czas (20 XII 1864), 217: 2

${ }^{92}$ Czas (28 XII 1864), 223: 1

${ }^{93}$ Czas (7 XII 1864), 207: 1.
} 
spowodowały, że nie ma już Polski, to dopóki trwa polska tożsamość narodowa, Rosja będzie mieć trudności z wcieleniem Królestwa ${ }^{94}$. Relacjonując $\mathrm{z}$ kolei doniesienia prasy francuskiej, na czele z La France, przypuszczano, że papież ma zaprotestować przeciwko kasacie klasztorów, która pogwałca konkordat z Rosją z roku 1847 i prawo kanoniczne. Spodziewano się również na święta Bożego Narodzenia encykliki papieskiej, w której z pewnością będzie mowa o likwidacji klasztorów w Królestwie. Pisząc zaś o reakcjach opinii publicznej we Francji redakcja Czasu stwierdziła, że wszyscy uważają akt kasacji za asymilację Polski do Rosji ${ }^{95}$. Doszło także, o czym zamieszczono notatkę na łamach krakowskiego dziennika, do ostrej polemiki między La France a Gazeta Moskiewska, która poczuła się urażona określeniami gazety francuskiej, wprost nazywającymi kasatę klasztorów „polowaniem na mnichów" "96. Polemika między prasą francuską a rosyjską w tej $\mathrm{i}$ innych kwestiach trwała zresztą dość długo ${ }^{97}$. Z ogromną aprobatą o kasatach pisały natomiast gazety pruskie na czele z Posener Zeitung czy Norddische allgemeine Zeitung, o czym krakowski dziennik informował bez specjalnego zdziwienia, mając na uwadze kasaty przeprowadzone w zaborze pruskim $^{98}$. Co ciekawe, w ogóle nie relacjonowano w Czasie artykułów z prasy austriackiej na temat kasat klasztornych ${ }^{99}$, ale jak wykazały badania Edwarda Walewandra, było ich niewiele, gdyż opinia publiczna była już po prostu zmęczona wydarzeniami w Polsce ${ }^{100}$. Z czasem prasę zachodnią zdominowały inne tematy. Dnia 22 XII 1864 r. Czas pisał: „Okropności popełniane przez Rosyan w Polsce wszystkich oburzają, ale mało kto już o nich pisze" $" 101$

${ }^{94}$ Czas (8 XII 1864), 208: 1.

${ }^{95}$ Czas (10 XII 1864), 209: 1.

${ }^{96}$ Czas (17 XII 1864), 215: 1.

${ }^{97}$ Czas (24 XII 1864), 221: 1.

${ }^{98}$ Czas (1 XII 1864), 202.

${ }^{99}$ Edward Walewander, Echa powstania styczniowego w prasie austriackiej (Warszawa: ODiSS, 1989), 114. Prasa austriacka co najmniej od kwietnia 1863 r. pisała o zamiarze kasat klasztorów przez rząd carski. Wiadomości te przyjmowano jednak z niedowierzaniem w środowiskach polskich, natomiast dla Austriaków, ze względu na dłuższe przygotowywanie opinii publicznej na ten fakt, likwidacja klasztorów w Królestwie Polskim w r. 1864 nie była żadnym zaskoczeniem. Oficjalnie zresztą Austria nie zaprotestowała przeciwko kasatom.

${ }^{100}$ Edward Walewander, „Represje carskie wobec Kościoła w Królestwie Polskim podczas powstania styczniowego w świetle prasy austriackiej”, Roczniki Teologiczno-Kanoniczne (1985), 32, 4: 154

${ }^{101}$ Czas (22 XII 1864), 219: 2. 
Szczególnie mocno podkreślano natomiast na łamach Czasu wszelkie przejawy zainteresowania papieża najpierw powstaniem, a potem sytuacją Polaków po jego upadku, jako wyrazu moralnego poparcia dla sprawy polskiej. Starano się zatem przypisać szczególne znaczenie każdemu gestowi i słowom sympatii ze strony Piusa IX lub z jego otoczenia ${ }^{102}$. Opisywano wszystkie audiencje papieskie, podczas których księża czy zakonnicy z ziem polskich dostąpili zaszczytu ucałowania stopy papieża, w jego minie, westchnieniu czy zapytaniu upatrując symbolicznego poparcia dla narodu polskiego ${ }^{103}$. Relacjonowano także każde oficjalne nabożeństwo, mszę, czy też prywatną modlitwę, w których Pius IX chociażby tylko wspomniał o Polsce, rozpisując się natomiast szeroko o alokucji z 24 IV 1864 r., w której zarządził modlić się za nieszczęśliwą Polskę ${ }^{104}$ i urządzeniu w Rzymie 6 IX tego roku procesji z obrazem Chrystusa, przed którym wierni mogli zanosić modły $\mathrm{w}$ tej intencji ${ }^{105}$. Prowadzoną przez Stolicę Apostolską politykę obrony religii katolickiej wręcz utożsamiano ze sprawą polską, nie do końca chcąc uwierzyć, że papieżowi tak naprawdę zależy tylko na obronie interesów Kościoła. Dlatego też, np. niedomagania zdrowotne Piusa IX redakcja Czasu interpretowała jako cierpienia głowy Kościoła na wieść o carskim ukazie ${ }^{106}$. Upatrywano także gniewu papieża na kasatę klasztorów w nagłych wyjazdach i powrotach do Rzymu Feliksa von Meyendorffa, przedstawiciela rosyjskiego przy Stolicy Apostolskiej ${ }^{107}$. Okazało się później, że przypuszczenia redakcji były zupełnie chybione, gdyż wyjeżdżał on do chorującego carewicza. Jak donoszono w korespondencji z Rzymu spodziewano się tam alokucji papieża w sprawie skasowanych klasztorów na najbliższym konsystorzu pod koniec roku. Wielkie nadzieje wiązano też z przygotowywaną przez papieża nową encykliką, której wydanie ogłaszano kilkakrotnie ${ }^{108}$. Encyklika papieska Quanta cura, wraz z tzw. Syllabusem błędów zostały przez Piusa IX podpisane 8 XII 1864 r., co podano do wiadomości wiernych 24 XII. Oba dokumenty zostały przedrukowane w całości przez Czas po łacinie i po polsku ${ }^{109}$.

\footnotetext{
${ }^{102}$ Krzysztof Lis, „Sprawy polskie w pontyfikacie Piusa IX (1846-1878)”, Saeculum Christianum: pismo historyczno-społeczne (2001), 8, 1: 108-110.

${ }^{103}$ Czas (12 VII 1864), 83: 1; (14 VII 1864), 85: 1; (22 VII 1864), 92: 2.

${ }^{104}$ Czas (7 V 1864), 30: 3; (8 V 1864), 31: 3; (10 V 1864), 32: 1, 3.

${ }^{105}$ Czas (8 IX 1863), 204: 2. Oba wydarzenia wywołały niemałą sensację w Europie i spowodowały stanowcze protesty Rosjan.

${ }^{106}$ Czas (20 XII 1864), 217: 1.

${ }^{107}$ Czas (23 XII 1864), 220: 1.

${ }^{108}$ Czas (20 XII 1864), 217: 3.

${ }^{109}$ Czas (30 XII 1864), 225: 2; (31 XII 1864), 226: 1-3; (6 I 1865), 5: 1-2, (6 I 1865), 5: 1-2.
} 
Zawierały one potępienie liberalizmu, socjalizmu, demokracji, nowożytnej filozofii i osiągnięć nauk przyrodniczych, ale nie było w nich mowy, ku zaskoczeniu redakcji, o potępieniu kasaty klasztorów w Królestwie. W krakowskim dzienniku tylko na ten fakt zwrócono uwagę, natomiast nie skomentowano innych treści dokumentów, przytaczając jedynie opinie zagraniczne (później w Czasie dokument umiarkowanie chwalono, wykazując jego słuszność). Mimo że zdawano sobie sprawę z ciężkiej sytuacji politycznej w Italii i bezpośredniego zagrożenia bytu Stolicy Apostolskiej, w papieżu wciąż widziano obrońcę sprawy polskiej i wymagano od niego zdecydowanych działań ${ }^{110}$. Powstało też silne przekonanie, że w kwestii klasztorów w Królestwie zostanie wydana osobna bulla ${ }^{111}$, zwłaszcza że papież wciąż zapewniał o swych modlitwach za Polskę i przyjmował na audiencjach zakonników ze skasowanych klasztorów. Spodziewanym wystąpieniem papieża $\mathrm{w}$ tej sprawie łudzono opinię publiczną jeszcze bardzo długo ${ }^{112}$, jak wiadomo bezskutecznie ${ }^{113}$, gdyż każde potępienie przez niego represji wobec Kościoła polskiego wiązało się od razu z ostrym potępieniem powstania i duchownych, którzy wzięli w nim udział. Memorandum papieskie, będące wyrazem protestu przeciwko kasacie klasztorów z marca 1865 r., nigdy nie zostało opublikowane, stanowiąc tylko element swoistej gry dyplomatycznej między Stolicą Apostolską a Europą ${ }^{114}$. Z pewnością w obojętnych mimo wszystko reakcjach zachodnich mocarstw i papiestwa na kasaty klasztorów w Królestwie ogromną rolę odegrała rosyjska propaganda. Opisując jej działania w sprawie „reform” kościelnych, zaprowadzanych przez rząd carski w Królestwie, redakcja Czasu strawestowała maksymę Woltera: „nie dość być szczęśliwym, trzeba jeszcze żeby wszyscy o tym wiedzieli”, pisząc że nie dość zaprowadzać reformy, trzeba aby w całej Europie wywołały podziw i zjednały uznanie ${ }^{115}$.

Tymczasem 28 XII 1864 r. Czas doniósł o kolejnym rozporządzeniu władz rosyjskich (z 4 XII), ograniczającym liczbę klasztorów męskich w Królestwie do 25 i żeńskich do 10. Miałyby to być tzw. klasztory etatowe, czyli podległe biskupowi, pozostałe stopniowo byłyby likwidowane. Ukaz

\footnotetext{
${ }^{110}$ Leopold Ranke, Dzieje papiestwa w XVI-XIX wieku, przeł. J. Zarański, Z. Żabicki (Warszawa: PIW, 1974), 668-684.

${ }^{111}$ Czas (24 XII 1864), 22: 4.

${ }^{112}$ Np. zob. Czas (4 III 1865), 52: 3; (20 IV 1865), 90: 1-2.

${ }^{113}$ Irena Koberdowa, „Papież Pius IX a powstanie styczniowe”, w: Szkice z dziejów papiestwa, t. 1, red. Irena Koberdowa, Janusz Tazbir (Warszawa: Książka i Wiedza, 1989), 230-231.

${ }^{114}$ Czas (12 III 1865), 59: 2.

${ }^{115}$ Czas (24 XII 1864), 221: 1.
} 
zawierał także szczegółowe instrukcje dotyczące funkcjonowania pozostawionych klasztorów oraz obowiązków zakonników i zakonnic. Także i ten dokument został w całości w krakowskim dzienniku przedrukowany w dwóch numerach $^{116}$, jednakże już bez komentarza, a tylko ze wzmianką, że zakonnicy ze skasowanych klasztorów są osadzani w Wielkopolsce na granicy z Prusami i władze pruskie, obawiając się, że przedostaną się bez żadnego dozoru na teren Prus, wysyłają przeciw nim oddziały wojskowe ${ }^{117}$. W wydaniu na koniec roku, podsumowując niedawne wydarzenia, warszawski korespondent Czasu napisał, że stało się to, co przewidywano przynajmniej od lata i niczego już w tej kwestii nie można dodać, a katolicy teraz jedynie wiarą i modlitwą powinni okazywać ufność w Opatrzność Bożą ${ }^{118}$. Za Moskiewskimi Wiadomościami powtórzono w styczniu 1865 r. mało optymistyczne myśli noworoczne o polskim narodzie i Kościele. Według rosyjskich dziennikarzy polska społeczność polityczna nie może istnieć wespół z rosyjską i dlatego musi się z nią zamalgamować i w niej zniknąć. Inaczej będzie zagrożony byt państwa rosyjskiego. Kościół katolicki nie zagraża natomiast wierze prawosławnej, ale należy oddzielić sprawy państwa od kwestii religijnych, a duchowieństwo nie będzie miało pobłażania u władz, jeżeli podejmie jakąkolwiek działalność polityczną ${ }^{119}$. Od nowego roku gazeta krakowska mniej już wspominała o losie klasztorów katolickich w Królestwie, podobnie jak prasa zagraniczna. Na podstawie korespondencji starano się jednak opisywać różne formy działania rządu carskiego wymierzone przeciw zakonom, jak np. poinformowano o ważnym rozporządzeniu Komisji Oświecenia Publicznego nakazującym rodzinom zabranie w wyznaczonym czasie dziewcząt z klasztornych szkół, ponieważ ulegną one likwidacji ${ }^{120}$ czy też o przeznaczeniu w Warszawie ogrodów po skasowanych klasztorach pod wytyczenie nowych ulic ${ }^{121}$. Coraz częściej też zarówno Czas, jak i inne gazety krajowe i zagraniczne zaczęły donosić o bliskim już wcieleniu Królestwa do Rosji, czemu stanowczo i długo zaprzeczała prasa prorosyjska ${ }^{122}$.

Opisując kasaty klasztorne w Królestwie Polskim i opatrując te wydarzenia odpowiednimi komentarzami redaktorzy Czasu mieli na celu pobudzenie sumienia zachodnich mocarstw i zmuszenie ich do zwarcia szeregów przeciw

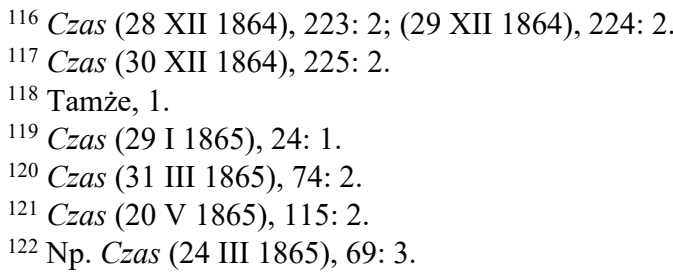


Rosji w obronie katolicyzmu. Starali się przy tym umiejętnie łączyć idee narodowo-wyzwoleńcze z religijnymi, będącą zresztą głęboko przekonanymi o ich koherentności. Liczono nie tylko na moralne poparcie dla narodu polskiego i katolicyzmu, ale także na podjęcie konkretnych i stanowczych zabiegów dyplomatycznych, angażując w nie również opinię publiczną w Europie. Szczególną rolę w tych działaniach przypisywano papieżowi, jako duchowemu ojcu i przywódcy religijnemu. Tymczasem państwa europejskie, poza wyrażeniem oburzenia na represje carskie wobec Kościoła polskiego, nie podjęły absolutnie żadnych działań, uważając że byłoby to mieszanie się w wewnętrzne sprawy Rosji. Z kolei Piusa IX bardziej interesowała obrona stanu posiadania Stolicy Apostolskiej oraz walka w obronie katolicyzmu przed wszelkimi nowościami, niż angażowanie się w otwarty konflikt z Rosją. W zaistniałej sytuacji, po chwilowym rewolucyjnym przebudzeniu, nastroje w redakcji Czasu stopniowo zaczęły się uspokajać a opisywane na łamach dziennika pojedyncze przykłady likwidacji klasztorów i inne działania rządu wobec duchowieństwa zakonnego w Królestwie Polskim nie spotykały się już z tak ostrą krytyką i zjadliwymi komentarzami, jak miało to miejsce bezpośrednio po ogłoszeniu carskiego ukazu.

\section{BIBLIOGRAFIA}

ŹRÓDŁA

Czas (1863), 16, 1-286, (1864), 17, 1-226; (1865), 18, 1-123.

Chwila (1863), 1; (1864), 74.

\section{OPRACOWANIA}

Adamek, Kazimierz. „Geneza i wstępny program krakowskiego 'Czasu”. Kwartalnik Historii Prasy Polskiej (1980), 19, 1: 29 (19-34).

Bańdo, Adam. „Krakowski 'Czas' (1848-1939) na tle dotychczasowych badań krakowskiej prasy”. Rocznik Historii Prasy Polskiej (2010), 13, 1-2: 81-95.

Bańdo, Adam. „W 'rezydencji' krakowskiego 'Czasu' (1848-1934)”. Rocznik Historii Prasy Polskiej (2014), 17, 2: 84-102.

Drobiszewski, Jerzy. „Kręgi czytelnicze 'Czasu' w latach 1848-1865”. Studia Historyczne (1969), 12, 3: 377-394.

Drobiszewski, Jerzy. „Serwis informacyjny dziennika 'Czas' w latach 1848-1865”. Zeszyty Prasoznawcze (1968), 9, 1: 74-86.

Figiela, Krzysztof. „Echa powstania styczniowego na łamach 'Czasu' i 'Gazety Narodowej'”. Zeszyty Naukowe Uniwersytetu Rzeszowskiego. Seria Socjologiczno-Historyczna (2003), 12 (Historia, 1): 51-58. 
Gach, Piotr Paweł. Kasaty zakonów na ziemiach dawnej Rzeczypospolitej i Śląska 1773-1914. Lublin: Redakcja Wydawnictw KUL, 1984.

Homola, Irena. „Prasa galicyjska w latach 1831-1866”. W: Historia prasy polskiej. Prasa polska 1661-1864. Red. Jerzy Łojek, 199-246. Warszawa: PWN, PAN IBL, 1976.

Jakubek, Mariusz. „Krakowski 'Czas' - środowisko dziennikarskie w latach 1848-1918”. Zeszyty Naukowe Uniwersytetu Jagiellońskiego (2005), 1279 (Prace Historyczne, 132): 147-166.

Koberdowa, Irena. „Papież Pius IX a powstanie styczniowe”. W: Szkice z dziejów papiestwa. T. 1. Red. Irena Koberdowa, Janusz Tazbir. Warszawa: Książka i Wiedza, 1989.

Lis, Krzysztof. „Sprawy polskie w pontyfikacie Piusa IX (1846-1878)”. Saeculum Christianum: pismo historyczno-społeczne (2001), 8, 1: 101-125.

Łojek, Jerzy, Jerzy Myśliński, Wiesław Władyka. Dzieje prasy polskiej. Warszawa: Wydawnictwo Interpress, 1988.

Olszański, Kazimierz. „Krakowski 'Czas' wobec powstania styczniowego”. W: Kraków w powstaniu styczniowym. Red. Kazimierz Olszański. (Biblioteka Krakowska nr 113), 193-301. Kraków: Wydawnictwo Literackie, 1968.

Olszański, Kazimierz. Prasa galicyjska wobec Powstania Styczniowego. (Prace Komisji Nauk Historycznych PAN, nr 35). Wrocław, 1975.

Prejs, Roland. Zakonnicy franciszkańscy Królestwa Polskiego po kasacie 1864 roku. Dzieje-postawy. Warszawa-Sandomierz: Bracia Mniejsi Kapucyni, Wydawnictwo Diecezjalne, 2003.

Skarbek, Jan. „Katarzyna Antonina Sowińska ze Schroederów, 1.v. Jonasowa (1776-1860), działaczka społeczna i charytatywna”. W: Polski słownik biograficzny. T. 40, z. 167. Red. Andrzej Romanowski, 632-633. Warszawa-Kraków, 2001.

Ranke, Leopold von. Dzieje papiestwa w XVI-XIX wieku. Przeł. J. Zarański, Z. Żabicki. Warszawa: PIW, 1974

Uljasz, Adrian. „Krakowski ‘Czas' wobec wybuchu i pierwszych tygodni powstania styczniowego. Studium historyczno-prasoznawcze”. W: Galicja a powstanie styczniowe. Red. Mariola Hoszowska, Agnieszka Kawalec, Leonida Zaszkilniak, 43-58. Warszawa-Rzeszów: DiG, 2013.

Walewander, Edward. Echa powstania styczniowego w prasie austriackiej. Warszawa: ODiSS, 1989.

Walewander, Edward. „Represje carskie wobec Kościoła w Królestwie Polskim podczas powstania styczniowego w świetle prasy austriackiej”. Roczniki Teologiczno-Kanoniczne (1985), 32, 4: $153-157$

Zieliński, Zygmunt. „Kościół ery popowstaniowej wobec nowych problemów. Powstanie styczniowe - sprawy, regiony, ludzie". Annales Universitatis Mariae Curie-Skłodowska (1993), 48, 4 (Historia): 29-39. 


\section{ECHA REPRESJI WOBEC KLASZTORÓW W KRÓLESTWIE POLSKIM NA ŁAMACH KRAKOWSKIEGO CZASU PO UPADKU POWSTANIA STYCZNIOWEGO}

\section{Streszczenie}

Ukazujący się w Krakowie od 1848 roku dziennik Czas, organ prasowy galicyjskich konserwatystów, na bieżąco informował czytelników o wydarzeniach w Królestwie Polskim związanych z powstaniem styczniowym i represjami rządu carskiego wobec Polaków po jego upadku. Jednym z głównych tematów były represje dotykające Kościół katolicki, a zwłaszcza męskie i żeńskie zakony. Czas opisywał wszelkie przejawy nękania osób zakonnych ze strony Rosjan: drobne złośliwości, wydawanie przepisów utrudniających normalne funkcjonowanie klasztorów, dręczenie moralne, stosowanie tortur, wykonywanie egzekucji i zsyłanie zakonników na Syberię, konfiskaty klasztornych majątków, a wreszcie likwidację większości klasztorów męskich i żeńskich. Przy okazji relacjonowania przypadków represji dziennik przedstawiał też reakcje zachodnich mocarstw i papiestwa na antypolską i antykościelną politykę caratu oraz nieskuteczne dyplomatyczne próby przeciwdziałania im. Długo łudzono czytelników nadzieją na zbrojną interwencję zachodnich mocarstw na rzecz uciemiężonego narodu polskiego, łącząc obronę idei narodowych z obroną religii katolickiej. Niestety nadzieje te, o czym Czas donosił z goryczą, okazały się płonne.

Słowa kluczowe: Królestwo Polskie; powstanie styczniowe; dziennik krakowski Czas; represje; klasztory męskie i żeńskie. 